\title{
EFL Student Challenges, Preferences, and Reactions towards Moodle-Based Online Learning under the New Normal in Indonesia
}

\author{
Mahmuda Akter ${ }^{1}$, Tono Suwartono ${ }^{2}$, and Muhammad Lookman Hossain Khan ${ }^{3}$ \\ \{mahmudakhan.dhaka@gmail.com ${ }^{1}$, suwartononewton@gmail.com² ${ }^{2}$ and \\ lhkhan.dhaka@gmail.com $\left.{ }^{3}\right\}$ \\ Department of English Education, School of Postgraduate, Universitas Muhammadiyah \\ Purwokerto, Central Java, Indonesia ${ }^{1}$ \\ Department of English Language Teaching, Faculty of Teacher Training and Education, \\ Universitas Muhammadiyah Purwokerto, Central Java, Indonesia ${ }^{2}$ \\ Department of Electrical Engineering and Information Technology, Universitas Gadjah \\ Mada, Yogyakarta, Indonesia ${ }^{3}$
}

\begin{abstract}
Online learning can play a significant role in continuing the teaching-learning process, especially during the pandemic. Moodle platform is one of the online learning solutions which is free. It is essential to justify and study student reactions, problems, and challenges using a Moodle-based online learning system for further successful online learning. This study aimed to investigate the EFL student challenges, issues, and reactions to the Moodle-based online learning system. The data were collected from 40 graduate and undergraduate EFL students from a private university in Central Java, Indonesia, through a questionnaire-based online survey. The data were analyzed using descriptive statistical techniques. Results of the study have shown that the most common challenges faced by the students were slow internet connection, over-loaded assignments with limited submission time, and health issues. Students believed that a slow connection increased their stress level. Besides, this study has revealed that the teacher's support was crucial in online learning using the Moodle-based system.
\end{abstract}

Keywords: students reactions, students challenges, students preferness, students health, new normal, pandemic, Covid-19.

\section{Introduction}

The novel coronavirus or Covid-19 has had the most devastating effect on the education sector. It initially occurred at the end of 2019 in the Chinese city of Wuhan. From Wuhan, it later spread to many different countries all everywhere in the world. World Health Organization declared it as 'Pandemic' in early 2020 due to its rapid spread [1,2]. Most countries declared a lockdown and later introduced everything as New Normal, but there were complications in education. About 61 countries already made the local take down to their citizen by closing the schools and universities [3].

Education is interrupted since the educational institutes cannot run their regular activities. According to Goyal, owing to the shutdown of educational institutions, about 600 million students have been affected in all the countries. According to UNESCO (2020), closing 
universities and schools has several adverse effects on students. Interruption of learning is the most common that can result in students deprived of education, development, and growth [4].

Since the government did not permit the institutions to open, it has been risky to open the institutions. The institutions are allowed to survive and continue the teaching and learning process using an online learning platform. Raju [5] argued that distance learning or online learning is a solution to continue education and overcome student stress and anxieties during the new normal period. Thus, distance online learning platforms can address this problem with internet-based learning. Learners are familiar with both online and distance learning. COVID19 , on the other hand, has reignited the urge to investigate online teaching and learning options.

Online learning can play a vital role in continuing the teaching-learning process, particularly during a pandemic. It provides facilities for teachers, students, administrators, and even parents. It is more practical to use it in a pandemic. For example, students can use it to download teachers' materials, can be engaged in some learning activity with teachers, and attend the exam on a laptop or mobile device from their home. Moreover, students can download the materials anytime, anywhere if their device has an internet connection.

UNESCO suggested solutions to the online learning system [4]. Many digital learning management systems are available on the web to deliver education. Edmodo, Google Classroom, Schoology, and Moodle are just a few examples. Moodle is a community-driven and globally-supported open learning platform. It provides various functions that are easy to integrate with other information systems of an educational institute [6]. Furthermore, it is open source and extensible. There are many other E-learning systems like [7].

The success of online learning depends on student's and teacher's capabilities. It also needs to confirm their willingness and acceptance of the platform [8,9]. Teacher's responsibility studentent's satisfaction is a vital parameter to measure the success of online learning. According to Khan, both the teachers and the students are positive of online learplatformstform [10]. However, a justification of student reactions, problems, and challenges of the Moodle-based online learning system is required for further successful online learning activities because the university's investment site is valuable and may hamper the overall development and growth of the students. To our best understanding, this subject is still in its infancy, where the students' opinions are not entirely studied [11,12]. Thus, this article explores student challenges, problems, and reactions to a Moodle-based online learning system at a private university in Central Java, Indonesia, during the New Normal period. Onclass UMP, a customized Moodlebased learning system, is used at the university.

\section{Literature Review}

\subsection{Indonesian government policy in pandemic}

The Indonesian government has taken some steps to tackle the Covid-19. They announced regulation of large-scale social restrictions until the newest rule is implemented, such as new normal regulation [13]. The Indonesian government purposefully created a policy in response to the pandemic breakout by requiring all educational institutions to host education, teaching, and learning at home by leveraging the online system. The Ministry of Education has mandated that all educational institutions use virtual classes. 


\subsection{Online learning platforms}

Through online lectures, teleconferencing, digital open books, online examinations, and interactivity in virtual worlds, COVID-19 causes a digital revolution in higher education $[14,15]$. Mpungose [16] discovered that students like Moodle as a learning management system. Students use Moodle to access course materials and module outlines. They also expressed an interest in taking quizzes. Because Moodle's discussion forum and bidirectional chat room were not user-friendly, the students were unsatisfied. Instead, they developed a WhatsApp group for fluid communication and exchange of ideas. The study suggested an informal e-learning platform (WhatsApp) to supplement formal e-learning platforms (Moodle) to meet student's personal needs [17]. Besides, many countries use Zoom, Teams, YouTube, Skype, Google Meets/Hangout, Google classroom, WhatsApp, and many more. Generally, social e-learning platforms such as Facebook, Twitter, and WhatsApp play a critical role in meeting societal communication needs during the higher education learning process. These platforms permit a student to create and share experiences. Higher education students are used to use social media in their everyday life. In Indonesia, Google Classroom is the most common online learning platform after zoom [19] shows various learning platforms used in Indonesia, which offer 57.1\% used Google Classroom and 21.4\% used Zoom.

\subsection{Challenges of online learning}

On one hand, new ICT difficulties constitute part of problems in developing country education policies, but on the other hand the necessity to account for the extensive usage of ICT outside of the [20] classroom for teaching and learning is undeniable [19]. Aung discovered that developing countries face trouble like insufficient internet connections, lack of awareness of ICT use, and a lack of content production [21]. It may result in unprepared and unqualified students in the future, because there is no readiness for incorporating online education into the study program at home during the Covid-19 outbreak [22]. There is a sharp distinction between those who can afford the means to use the new education platform and those who cannot [23].

\subsection{Student challenges in online learning}

Numerous studies found many challenges such as materials, communication, and data bundles in online learning. Technology issues, e-learning system quality elements, cultural elements, self-efficacy elements, and trust elements, according to Yawson, are the common problems in E-learning. Furthermore, the findings revealed that there are three primary obstacles to using an e-learning system: (1) change management concerns, (2) e-learning system technical concerns, and (3) financial support concerns [24]. Lack of e-learning assistance, students' unfamiliarity with the English language, infrastructural issues, students' lack of computer skills, and a lack of financing for research and encouragement are primary barriers to E-learning [25]. 


\section{Research Methods}

\subsection{Participants}

This survey aimed to discover the challenges, preferences, and reactions of the EFL students on the online learning system during the New Normal period at the university level. The survey drew the participation of 40 undergraduate and postgraduate EFL students. They were students at a private university in Banyumas, Central Java, Indonesia, majoring in English Language Teaching or English Education.

Table 1. Distribution of the participants.

\begin{tabular}{ll}
\hline Degree Level & Number of Participants \\
\hline Undergraduate & 17 (5 Male, 12 Female) \\
Graduate & 23 (4 Male, 19 Female) \\
Total & 40 (9 Male, 31 Female) \\
\hline
\end{tabular}

The survey was conducted in February 2021. The researcher selected the participants based on the random sampling technique. Table 1 displays the degree level and the number of participants to describe the distribution of the respondents. There were 17 respondents from the undergraduate level; five of them were males and twelve females. Meanwhile, among the graduate students, 23 respondents were recruited, out of whom four were male, nine were female. The total respondents were 40 , nine of them male and 31 females.

\subsection{Instrument}

A questionnaire-based online survey was used in the study. It was used to collect data on student problems, preferences, and reactions to Moodle-based online learning. The online questionnaire consisted of close-ended questions and open-ended questions. According to Newlove [26], students can express their thoughts and reactions more freely using open-ended questions. The closed-ended questions inquired about the students' experiences with their concerns in the online class. The closed-ended questions were related to student reactions to online learning, teacher's support, LMS Moodle of the university, internet connection, and stress level. There were two parts of closed-ended questions. The first part consisted of multiplechoice questions related to student reactions to online learning. The other part of the close-ended questions dealt with student preferences of online learning. The close-ended questions used a 5-point Likert scale ranging from 1 to 5 as a rating where one represents "strongly disagree" and five means "strongly agree." Under the open-ended questions section, few questions were related to measuring stress level, teacher's support, and LMS easiness. The questionnaire was validated using expert judgment by two e-learning experts: one, an IT expert, working as a software developer, and a researcher who is an expert in the e-learning area. 


\subsection{Procedure}

The researcher transformed the hard copy of the questionnaire into Microsoft Forms. It is easy to use and user-friendly. It gives some extra facilities over Google Form. The online survey form URL was then shortened at https://www.shorturl.at website to make the URL look nice and short. The URL with a short message was then distributed to the undergraduate (S1) and graduate (S2) students of English Language Education. The researcher sent the URL via the respective department heads to get higher privileges from the students. The URL and the guidance were sent via WhatsApp, considering that it is a common platform in Indonesia, and each study program has a WhatsApp group. The researcher used the simple random sampling technique to regulate the instrument to target participants.

\subsection{Data analysis}

The data of the online survey were downloaded from Microsoft Form as an Excel file. A descriptive research analysis technique was used to understand the frequency, distribution of the respondents and the Likert scale data. Close-ended questions, on the other hand, were analyzed using SPSS software. The author used a descriptive statistics technique to examine the close-ended data. The open-ended question was analyzed using a content analysis method.

\section{Results and Discussion}

\subsection{EFL student's significant challenges in online learning}

The questionnaire contained an open-ended question related to the student's primary challenges or problems in online learning. The open-ended data were analyzed inductively using the qualitative content analysis technique. Online learning brings unique challenges to students [27]. Students' most common obstacle in online learning is the poor internet connection at their homes [28]. Table 2 shows the primary challenges faced by the students in their online classes attending from their home.

Table 2. Primary challenges in online learning.

\begin{tabular}{lll}
\hline Challenges & Respondents & Percentage \\
\hline Internet Connection & 17 & 42.5 \\
Understanding Material & 8 & 20 \\
Assignments Deadline & 6 & 15 \\
Overloaded Assignments & 5 & 12.5 \\
Health Issue & 5 & 12.5 \\
Communication & 2 & 5 \\
\hline
\end{tabular}

Table 2 indicates that the internet connection takes first place among the problems or challenges they faced. There were $17(42.5 \%)$ respondents out of 40 who faced major internet connection problems. The students believed that limited quota, poor internet connection, and unstable mobile data connection were the major problems. Few students had to install Wi-Fi in 
their homes due to finding a good mobile signal in their areas. Understanding Material ranks second among other problem groups. The material delivered to the students by the teachers while online teaching was quite hard. A previous study showed that the difficulty in understanding the objectives of the online courses was a challenge [29]. According to the above result, about $20 \%$ of the students believed that the lecture was very tough to understand due to drooped voice and unstable internet connection. Moreover, it was challenging for the students to concentrate.

Assignments were also one of the primary challenges faced by students. The result has shown that $27 \%$ percent of the students believed that a job is one of the primary challenges they faced during online learning. According to Livana et al., the learning task is the primary factor that causes stress to students during the pandemic Covid-19 [30]. Approximately 12.5 percent of students agreed that they were overworked. Students in an online learning environment feel a high burden [31]. Some students said they were given assignments instead of giving a class lecture. The teacher needs to understand the student's situation. They need to make sure they can do the task within due time. A teacher also needs to consider student's technical competencies. Because the students have to do the assignments on computer and they need internet access to do so. A teacher should give the students flexible time for assignments submission. Fifteen percent of the students believed that the time allotted for completing the activities was insufficient. The primary obstacle in online learning, according to Lora, is time management [32]. Thus, a flexible time will be a better option to reduce student workload.

The respondents agreed that the workload increased their stress levels. Some students got sick, and $12.5 \%$ of them gave their opinion about health issues. They said they experienced problems with their eyes due to online classes and too many assignments they had to do with a computer, which was in line with the results of a study by Octaberlina and Muslimin [33]. Students feel more stressed in online learning than in face-to-face learning [27]. Furthermore, the effects of stress have an impact on every system in our bodies [34]. Studies found that extended periods working on mobile or computer leads to physical harm [35]. The intensity of mental health issues among college students can strain mental health facilities, resulting in long wait times for care [36]. Since the Covid-19 pandemic, the quick shift from face-to-face learning to online learning in the educational system might have caused intense stress on students [37]. Kapasia et al. found that most students suffer from stress, depression, and anxiety in online learning [18]. The current study results also found that students experienced other minor health issues due to increased stress levels. Eventually, only 5\% of students reported communication complexity with their teachers in further understanding of assignments. According to Hasan, teachers should consider and suggest the students have a healthy body. Besides, they should keep away students from the psychological effect of online learning, such as stress and being afraid of academic loss and the score. Thus, Hasan and Bao [18] suggested that teachers improve their teaching and learning plans and professional competence.

\subsection{EFL student's preferences of online learning}

Figure 1 shows the student's preference of learning mode between online and face-to-face to class delivery. The result indicates that a significant number of students prefer face-to-face classes instead of online courses. Among the students, $68 \%$ of students prefer face-to-face courses, whereas $32 \%$ prefer online learning. Krishnapatria found that $56 \%$ of students were 
satisfied, and $44 \%$ were dissatisfied with their online learning experience [19]. According to Abbasi, traditional learning is better than online learning [38]. However, a study in Oman revealed that most students prefer online mode instead of face-to-face [39].

Figure 2 shows the students' preference for the opening camera during online classes. The result demonstrated that $33 \%$ of students preferred to open the camera during online learning, $30 \%$ of students did not want to open the camera during online classes, and $38 \%$ did not give their opinion.

Figure 3 illustrates the importance of support from the teachers in solving student problems in online learning. The result has indicated that $25 \%$ of students agreed to the teacher's help. They believed their teachers would help them if they faced any problems during online classes. Only about $8 \%$ of students disagreed that their teacher did not care about the difficulties in online learning. However, $30 \%$ of students did not give their opinion between Yes and No. Hasan and Bao [40] found that To have a meaningful teaching and learning process, teachers should slow down their explanations so that students may understand and remember the ideas discussed in the online session.

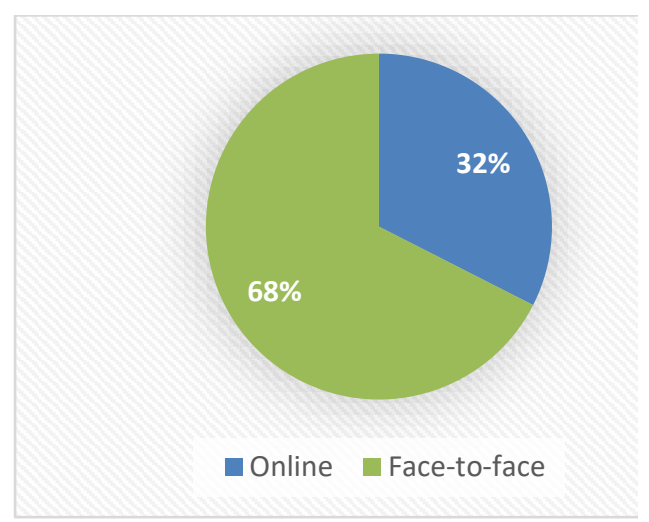

Figure 1. Online versus face-to-face learning.

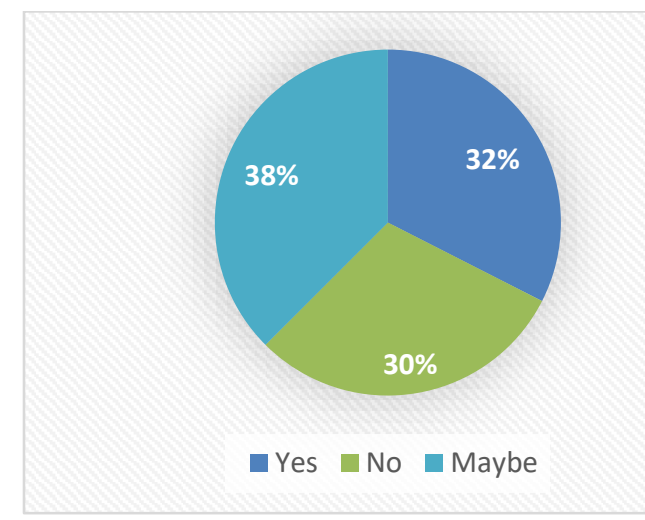

Figure 2. Student reactions to the use of webcamera.

Supporting online learning and maintain a healthy and friendly relationship can make online learning more enjoyable [41]. Cambridge Assessment International Education [42] shows that To enhance their readiness in tackling online education, the majority of Indonesian scholars have been ICT literate. Teachers should contact learners to find out what type of assistance they require. They also need to find a way to support them, especially the technical and technological problems students may face in online learning [43]. Additionally, online teachers need to be given training in multiple areas to best support their students [44-46]. 


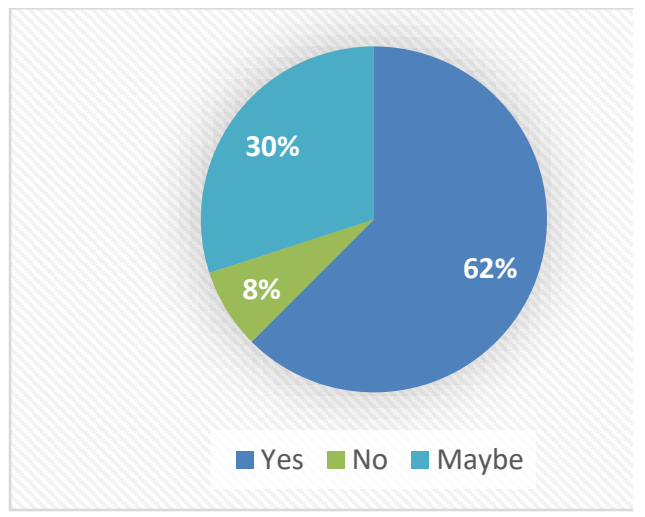

Figure 3. Teacher's support in solving students' problems of online classes.

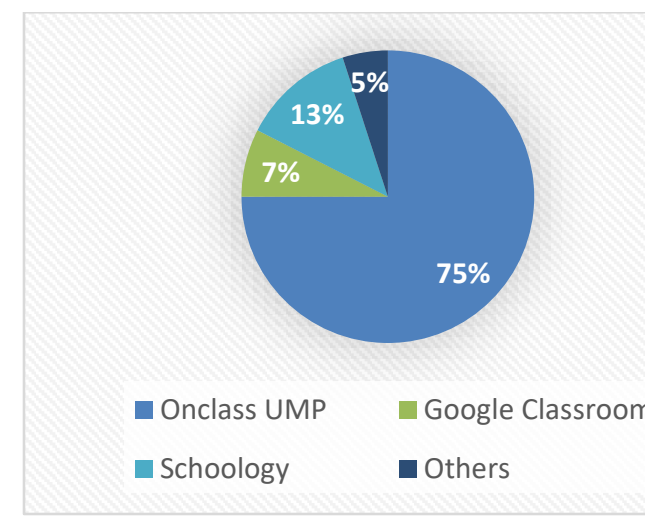

Figure 4. Student preferences of LMS platform.

Figure 4 illustrates the students' preference for the Learning System (LMS) in online learning. The result has indicated that a significant number of $75 \%$ of students preferred Onclass UMP for online classes. However, only $8 \%$ of students chose Google Classroom, $13 \%$ of students selected Schoology, and the remaining (5\%) students preferred other LMS Apps in online learning. It seems that the students were a little bit biased while giving opinions in preference of the LMS platform. Table 3 shows that the On class was quite hard to operate, and the usability score was also low.

On the contrary, they preferred the On-class UMP platform. If we put Onclass UMP back, this study would show that the students chose Schoology followed by Google classroom. Schoology has some advantages in teaching compared to others. Schoology with Slido can be a very effective tool for online education. However, Google Classroom is a widely used LMS Platform in Indonesia [47]. Google Classroom is also effective in teaching as it is very light and user-friendly. The advantages students and teachers can take from Google Classroom are that most of them already have Google account. Thus, they do not have to create new accounts. Besides, Google provides cloud office tools such as Google Form, Word, Excel, and Presentation apps with $15 \mathrm{~GB}$ of free storage. Studies in Indonesia proved that Google Classroom is an effective tool in online learning and that the majority of Indonesian students increase their attendance in Google Classroom classes [48-50].
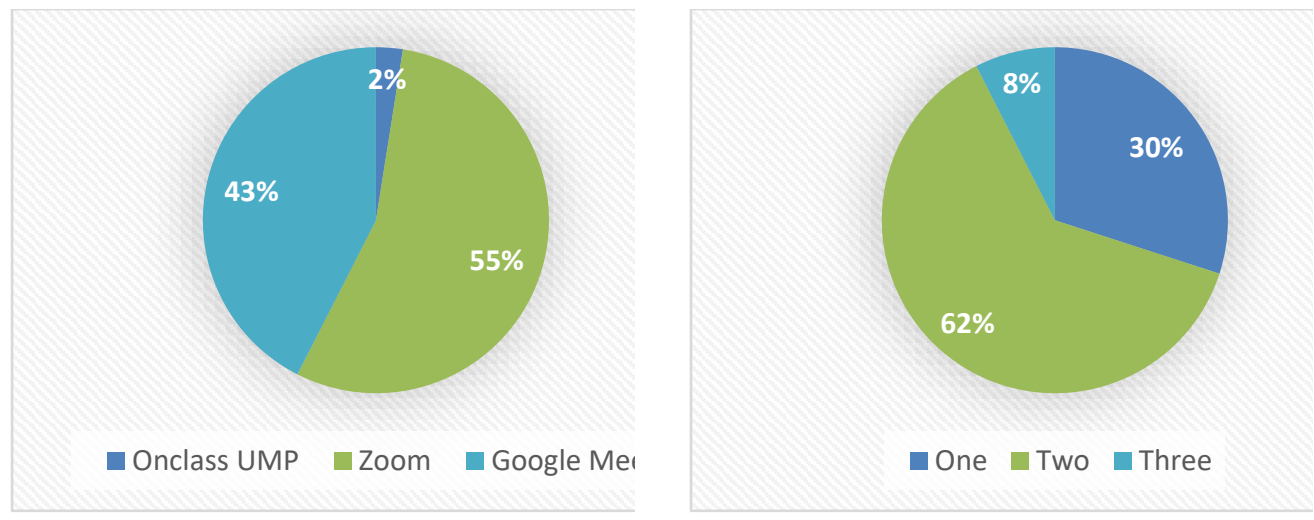
Figure 5. Student preferences of web meeting apps.
Figure 6. The number of devices used by students.

Figure 5 shows the students' preference for video meetings during online classes. The result has indicated that about $55 \%$ of students preferred Zoom for a video meeting, whereas only $3 \%$ of students preferred Onclass UMP, and 43\% of students prefer Google Meet. Figure 6 shows the number of devices that students used during online classes. The result demonstrated that a significant number of around $62 \%$ used two devices during online learning, whereas $30 \%$ used one device. However, surprisingly enough, $8 \%$ of students used up to three devices during online learning. Table 3 shows the students' opinion on Moodle's usability. According to the results, Moodle was not so comfortable to use on a mobile device. The majority of students used two devices because they could do the task from the mobile phone. However, a study found that EFL teachers are positively motivated to use Mobile in online teaching [51]. Thus, a mobilefriendly Moodle system is required to develop.

Figure 7 illustrates the class duration in online learning according to the EFL student's perspective. The result has shown that $50 \%$ of the students believed the online class should not be more than one hour, $23 \%$ of students accepted class duration should be more than one hour, and the remaining (28\%) students did not give their opinion in-between Yes and No. A short class is the best. Since students attend classes from home, there must be some obstacles. Classroom conditions and home conditions are different. Usually, students have activities at their homes. Considering their surroundings, they have to engage with other work. Since the pandemic breakout, students have been back to their traditional homes. They depend on cellular internet connection. The internet speed is limited in rural areas compared to the city. Even finding a better cellular signal is difficult. They need to go to the city or finding a Wi-Fi area. Considering all the aspects, a short class is better in an online learning situation. Besides, the teachers can think about asynchronous learning. The results showed that $50 \%$ of students believed the class duration should not be more than an hour. An earlier study also suggests that class duration should be reduced [52].

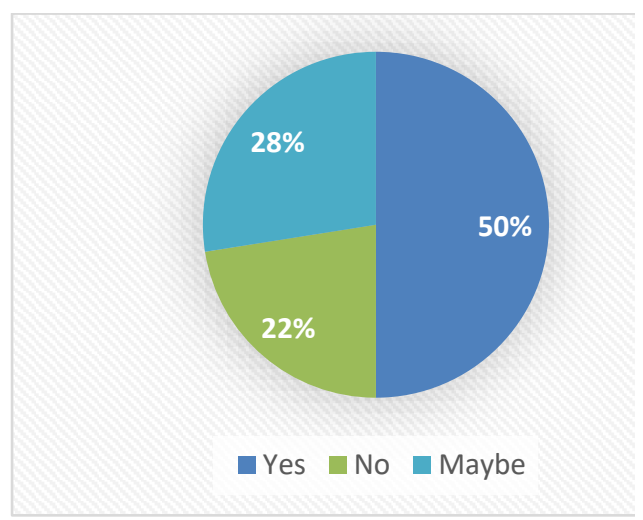

Figure 7. Student's opinion of online class duration.

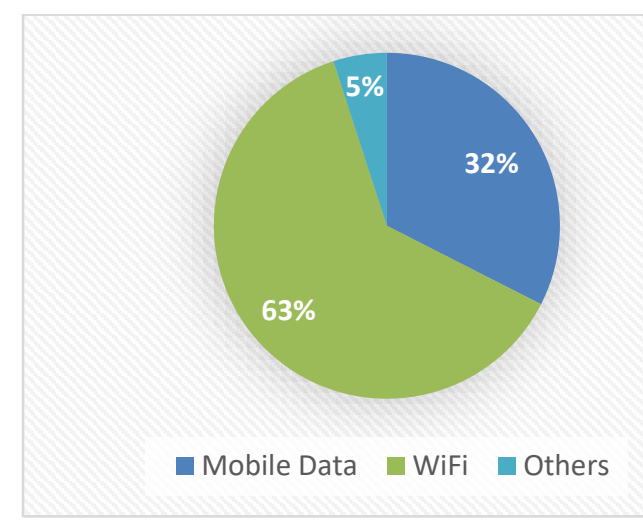

Figure 8. Type of internet connection. 
Figure 8 shows the type of internet connection that students used during online learning. The result demonstrated that about $63 \%$ of the students used Wi-Fi in online education, 33\% used mobile data, and only a tiny portion $(5 \%)$ of students used other internet connection types.

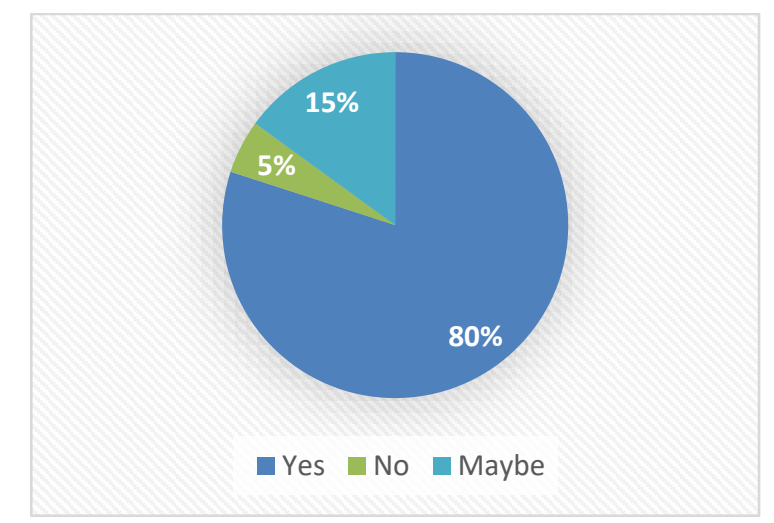

Figure 9. Student's stress level due to connection speed.

Figure 9 illustrates the reactions of the EFL students regarding stress levels in online learning. The result has shown that $80 \%$ of the students agreed that poor internet connection increased their stress level during online classes. In contrast, only 5\% of students said that slow connection did not increase their stress level during online learning. The remaining $15 \%$ of students did not give their opinion in-between Yes and No. The previous study found that students have poor internet connectivity in online learning. According to previous studies, having a bad connection can increase stress levels [18,53].

\subsection{EFL student's reactions to an online learning platform}

Table 3 shows the result of the descriptive statistics on reactions of the EFL students towards online learning. The result has indicated that the importance of teacher's support and teacher's support in online learning reached the highest average scores of 4.60 and 4.03. With the standard deviations of 0.81 and 0.73 , they took the first and second positions, respectively. On the other side of the coin, the easiness of operating the On-class system and usability of Moodle platform took the last places with average scores of 2.42 and 2.03 sequentially. Mpungose found that students face some difficulties using Moodle [17].

Table 3. Descriptive statistics of student reactions to online learning.

\begin{tabular}{lll}
\hline Variables & Mean & $\begin{array}{l}\text { Std. } \\
\text { Deviation }\end{array}$ \\
\hline Importance of Teacher's Support & 4.6 & 0.81 \\
Teacher's Support in Online Learning & 4.03 & 0.73 \\
Overall Rating of On class & 3.88 & 0.85 \\
Challenges of online class using Moodle & 3.75 & 0.90 \\
Platform & 3.68 & 0.97 \\
Internet Connection Speed & 2.42 & 1.09 \\
Easiness of Operating On class & 2.03 & 1.23 \\
Usability of Moodle Platform & &
\end{tabular}


The students preferred Moodle for uploading materials uploads instead of conducting whole online activities. They believed Moodle is not user-friendly. The results have shown that the overall rating of the On class attribute averaged 3.88. The challenges of the online class scored a mean value of 3.75. Internet connection speed scored a mean value of 3.68. According to a study, students' reactions to the internet connection were $21.4 \%$ Very Good, $84.3 \%$ Good, and $14.3 \% \mathrm{Bad}$ in online learning [19]. Overall, the importance of teacher's support had the highest mean score, whereas the usability of Moodle platform of a native speaker (teacher) recorded the lowest mean score. Moreover, Moodle is not user-friendly, and it has confusing functions [17].

\section{Conclusion}

This study revealed the primary challenges of the EFL students in online learning during pandemic New Normal period. The slow internet connection, over-loaded assignments with limited submitting time, and health issues are the primary challenges. Besides, students have faced difficulties in understanding lecture materials. The students cannot concentrate on their classes due to drooped voices and other factors. Students believe that a slow connection increases their stress level. They also think about the importance of teacher's supports in online learning. This study was limited to a university level, with a limited number of participants. Further studies should be conducted in a wide range of universities. Further research should uncover the reasons behind the students' stress. Besides, types of Moodle-based solutions for students are required. This study contributes to the current literature, and it will be a guideline for the teachers to find proper materials which can help engage students in their online classes.

\section{References}

[1] Mizumoto K, Kagaya K, Zarebski A, Chowell G. Estimating the asymptomatic proportion of coronavirus disease 2019 (COVID-19) cases on board the Diamond Princess cruise ship, Yokohama, Japan, 2020. Eurosurveillance. 2020;25(10):2000180.

[2] Pelmin M. Readings on Coronavirus Disease (COVID-19) and the Higher Education Institution (HEIs) Emergency Preparedness in the Philippines. Available SSRN 3573896. 2020;

[3] Unesco. School closures caused by Coronavirus (Covid-19) [Internet]. 2020 [cited $2021 \mathrm{Feb}$ 16]. Available from: https://en.unesco.org/covid19/educationresponse/

[4] Unesco. Distance learning solutions [Internet]. 2020 [cited 2021 Feb 8]. Available from: https://en.unesco.org/covid19/educationresponse/solutions

[5] Raju E, Ayeb-Karlsson S. COVID-19: How do you self-isolate in a refugee camp? Int J Public Health. 2020;65(5):515-7.

[6] V. Butova A, I. Dubskikh A, V. Kisel O, G. Chigintseva E. Electronic Educational Environment Moodle in English Language Training. Arab World English J. 2019;10(1):47-55.

[7] Khan MLH, Setiawan A, Kustiawan I. Design and Development of A Single Page and Webbased Responsive E-learning System for Higher Education Institutions. INVOTEC. 2019;15(2):85-93.

[8] Almaiah MA, Alismaiel OA. Examination of factors influencing the use of mobile learning system: An empirical study. Educ Inf Technol. 2019;24(1):885-909.

[9] Shawai YG, Almaiah MA. Malay language mobile learning system (MLMLS) using NFC technology. Int J Educ Manag Eng. 2018;8(2):1. 
[10] Khan MLH, Setiawan A. The impact of E-learning on higher education perception, skills, critical thinking and satisfaction. In: Journal of Physics: Conference Series. IOP Publishing; 2019. p. 12084.

[11] Almaiah MA, Alamri MM. Proposing a new technical quality requirements for mobile learning applications. J Theor Appl Inf Technol. 2018;96(19).

[12] Tarhini A, Hone K, Liu X, Tarhini T. Examining the moderating effect of individual-level cultural values on users' acceptance of E-learning in developing countries: a structural equation modeling of an extended technology acceptance model. Interact Learn Environ. 2017;25(3):306-28.

[13] Pragholapati A. New Normal "Indonesia" After Covid-19 Pandemic. 2020;2019:1-6.

[14] Jena PK. Impact of Covid-19 on higher education in India. Int J Adv Educ Res. 2020;5.

[15] Strielkowski W. COVID-19 pandemic and the digital revolution in academia and higher education. 2020;

[16] Khoza S, Mpungose C. Use of the Moodle curriculum by lecturers at a South African University. In: ICEL 2018 13th international conference on e-Learning. Academic Conferences and publishing limited; 2018. p. 171.

[17] Mpungose CB. Is Moodle or WhatsApp the preferred e-learning platform at a South African university? First-year students' experiences. Educ Inf Technol. 2020;25(2):927-41.

[18] Kapasia N, Paul P, Roy A, Saha J, Zaveri A, Mallick R, et al. Impact of lockdown on learning status of undergraduate and postgraduate students during COVID-19 pandemic in West Bengal, India. Child Youth Serv Rev [Internet]. 2020;116:105194. Available from: https://doi.org/10.1016/j.childyouth.2020.105194

[19] Krishnapatria K. From 'Lockdown' to Letdown: Students' Perception of E-learning amid the COVID-19 Outbreak. ELT Focus. 2020;3(1):1-8.

[20] Hinostroza JE. New challenges for ICT in education policies in developing countries: The need to account for the widespread use of ICT for teaching and learning outside the school. ICTSupported Innov small Ctries Dev Reg. 2018;99-119.

[21] Aung TN, Khaing SS. Challenges of implementing e-learning in developing countries: A review. In: International Conference on Genetic and Evolutionary Computing. Springer; 2015. p. 405-11.

[22] Hariyadi S, Martiarini N, Anto AHF. Career Decision Self Efficacy and Psychological Distress in Non-Formal Education Students. Int J Indian Psychol. 2019;7(1):270.

[23] Magsambol B. FAST FACTS: DepEd's Distance Learning. Pasig, PH: Rappler; 2020.

[24] Aboagye E, Yawson JA, Appiah KN. COVID-19 and E-Learning: the Challenges of Students in Tertiary Institutions. Soc Educ Res. 2020;2(1):109-15.

[25] Kumar S. Awareness, Benefits and Challenges of e-Learning among the Students of Kurukshetra University Kurukshetra: A Study. Int J Inf Dissem Technol. 2018;8(4):227.

[26] Newlove BW, Hall GE. A Manual for Assessing Open-Ended Statements of Concern About an Innovation. 1976;

[27] Lazarevic B, Bentz D. Student perception of stress in online and face-to-face learning: the exploration of stress determinants. Am J Distance Educ. 2020;1-14.

[28] Gilbert B. Online learning revealing the benefits and challenges. 2015;

[29] Song L, Singleton ES, Hill JR, Koh MH. Improving online learning: Student perceptions of useful and challenging characteristics. Internet High Educ [Internet]. 2004;7(1):59-70. Available from: https://www.sciencedirect.com/science/article/pii/S1096751603000885

[30] Livana PH, Mubin MF, Basthomi Y. “Learning Task” Attributable to Students' Stress During the Pandemic Covid-19. J Ilmu Keperawatan Jiwa. 2020;3(2):203-8.

[31] Valaitis RK, Sword WA, Jones B, Hodges A. Problem-based learning online: perceptions of health science students. Adv Heal Sci Educ. 2005;10(3):231-52.

[32] Seifert T. Student assessment in online learning: Challenges and effective practices during Covid-19. In: EdMedia+ Innovate Learning. Association for the Advancement of Computing in Education (AACE); 2020. p. 106-8.

[33] Octaberlina LR, Muslimin AI. Efl students perspective towards online learning barriers and 
alternatives using moodle/google classroom during covid-19 pandemic. Int J High Educ. 2020;9(6):1-9.

[34] Schooler TY, Dougall A, Baum A, Kazdin AE. Stress: Impact on health. Encycl Psychol. 2000;7:487-9.

[35] Kersting XAK, Hirsch S, Steinert T. Physical harm and death in the context of coercive measures in psychiatric patients: A systematic review. Front psychiatry. 2019;10:400.

[36] Kitzrow MA. The mental health needs of today's college students: Challenges and recommendations. NASPA J. 2003;41(1):167-81.

[37] Moawad RA. Online learning during the COVID-19 pandemic and academic stress in university students. Rev Românească pentru Educ Multidimens. 2020;12(1 Sup2):100-7.

[38] Abbasi S, Ayoob T, Malik A, Memon SI. Perceptions of students regarding e-learning during covid-19 at a private medical college. Pakistan J Med Sci. 2020;36(COVID19-S4):S57-61.

[39] Syahrin S, Abdalla Salih A. An ESL Online Classroom Experience in Oman during Covid-19. Arab World English J. 2020;11(3):42-55.

[40] Hasan N, Bao Y. Impact of "e-Learning crack-up" perception on psychological distress among college students during COVID-19 pandemic: A mediating role of "fear of academic year loss." Child Youth Serv Rev. 2020;118:105355.

[41] Suwartono T, Khan MLH, Akter M. Students' Reactions to Learning English as a Foreign Language at an Indonesian College. Int J Psychosoc Rehabil. 2020;24(8):3596-609.

[42] Widyanti A, Hasudungan S, Park J. e-Learning readiness and perceived learning workload among students in an Indonesian university. Knowl Manag E-Learning An Int J. 2020;12(1):1829.

[43] Lee SJ, Srinivasan S, Trail T, Lewis D, Lopez S. Examining the relationship among student perception of support, course satisfaction, and learning outcomes in online learning. Internet High Educ [Internet]. 2011;14(3):158-63. Available from: https://www.sciencedirect.com/science/article/pii/S1096751611000236

[44] Ghounane N. Moodle or Social Networks: What Alternative Refuge is Appropriate to Algerian EFL Students to Learn during Covid-19 Pandemic. Arab World English J. 2020;11(3):21-41.

[45] Suwartono T, Aniuranti A. Digital Teaching Tools in 21st Century EFL Classroom: Are Our Teachers Ready? ELLITE J English Lang Lit Teach. 2019;3(2):57.

[46] Zweig J, Stafford E. Training for Online Teachers to Support Student Success: Themes from a Survey Administered to Teachers in Four Online Learning Programs. J Online Learn Res [Internet]. 2016;2(4):399-418. Available from: https://www.learntechlib.org/p/172573

[47] Zulfa V, Laras P. Schoology and Slido: The Perfect Platform Combination for Distance Learning During the Covid-19 Pandemic. In: Proceedings of the International Joint Conference on Science and Engineering (IJCSE 2020) [Internet]. Atlantis Press; 2020. p. 86-91. Available from: https://doi.org/10.2991/aer.k.201124.016

[48] Okmawati M. The Use of Google Classroom during Pandemic. J English Lang Teach. 2020;9(2):438

[49] Sutrisno S. Increased Learning Activities and Outcomes through Online Learning with Google Classroom in the COVID-19 Pandemic Period. Ideguru J Karya Ilm Guru [Internet]. 2020;5(1):95-. Available from: https://jurnaldikpora.jogjaprov.go.id/index.php/jurnalideguru/article/view/151

[50] Ph L, Basthomi Y, Sari RK, Wakhid A. Learning Media Used by Indonesian Students During the Pandemic Covid 19. 2020;19-22.

[51] Van Vo L, Thuy Vo L. EFL Teachers' Attitudes towards the Use of Mobile Devices in Learning English at A University in Vietnam. Arab World English J. 2020;11(1):114-23.

[52] Law L, Hafiz M, Kwong T, Wong E. Enhancing SPOC-flipped classroom learning by using student-centred mobile learning tools. In: Emerging technologies and pedagogies in the curriculum. Springer; 2020. p. 315-33.

[53] Cahyadi A. Covid-19 Outbreak and New Normal Teaching in Higher Education: Empirical Resolve from Islamic Universities in Indonesia. Din Ilmu. 2020;20(2):255-66. 